CORRECTION

\title{
Correction to: SFRP2 induces a mesenchymal subtype transition by suppression of SOX2 in glioblastoma
}

Min Guo (D), Kaveh M. Goudarzi, Shiva Abedi, Melanie Pieber, Elin Sjöberg (D), Jinan Behnan (D), Xing-Mei Zhang, Robert A. Harris, Jiri Bartek, Mikael S. Lindström (D), Monica Nistér (D) and Daniel Hägerstrand (D)

(c) The Author(s) 2021

Oncogene (2021) 40:5153; https://doi.org/10.1038/s41388-021-01929-9

Correction to: Oncogene https://doi.org/10.1038/s41388-02101825-2, published online 21 May 2021

Unfortunately, the second corresponding author was not given in the Original article.

The second corresponding author is:

Daniel Hägerstrand, Email: daniel.hagerstrand@ki.se

The original article has been corrected.

\begin{abstract}
(c) (i) Open Access This article is licensed under a Creative Commons Attribution 4.0 International License, which permits use, sharing, adaptation, distribution and reproduction in any medium or format, as long as you give appropriate credit to the original author(s) and the source, provide a link to the Creative Commons license, and indicate if changes were made. The images or other third party material in this article are included in the article's Creative Commons license, unless indicated otherwise in a credit line to the material. If material is not included in the article's Creative Commons license and your intended use is not permitted by statutory regulation or exceeds the permitted use, you will need to obtain permission directly from the copyright holder. To view a copy of this license, visit http://creativecommons. org/licenses/by/4.0/.
\end{abstract}

() The Author(s) 2021 